\title{
The Discourse of Muhammadiyah and Nahdlatul Ulama with Considerations of Geertz's Religion of Java
}

\author{
Firdaus Wajdi \\ Universitas Negeri Jakarta \\ firdaus.wajdi@unj.ac.id \\ Naskah diterima:17 Desember 2017, direvisi:26 Januari 2018; disetujui:29 Januari 2018
}

\begin{abstract}
Abstrak
Muhammadiyah dan Nahdlatul Ulama adalah dua organisasi Muslim terbesar di negara berpenduduk Muslim terbanyak, Indonesia. Banyak penelitian telah dilakukan untuk mengidentifikasi kedua peran tersebut dalam konteks Islam Indonesia. Namun, ada kekurangan studi untuk menelusuri kemungkinan kesamaan antara keduanya. Paper ini menggambarkan deskripsi yang berbeda dari kedua organisasi tersebut dari perspektif Clifford Geertz dalam karya utamanya, the Religion of Java, di mana Geertz meliput beberapa karakteristik pengikut Muhammadiyah dan Nahdlatul Ulama. Studi ini kemudian berlanjut dengan identifikasi common grounds dari Muhammadiyah dan Nahdlatul Ulama. Penelitian kualitatif ini dilakukan melalui penelitian kepustakaan. Studi ini menyimpulkan bahwa terlepas dari kenyataan perbedaannya, ada beberapa kesamaan, yang membuat kedua organisasi tersebut bersama-sama berkontribusi lebih pada pengembangan Islam di Indonesia. Kemudian diharapkan para pengikutnya untuk bisa bekerja sama untuk membangun Indonesia yang damai melalui pemahaman yang lebih baik tentang institusi keagamaan Islam seperti Muhammadiyah dan Nahdlatul Ulama.
\end{abstract}

Kata kunci: Muhammadiyah, Nahdlatul Ulama, Clifford Geertz.

\section{Abstract}

Muhammadiyah and Nahdlatul Ulama are two biggest Muslim organizations in the most populous Muslim country, Indonesia. Many studies have conducted to identify both roles in the Indonesian Islam context. However, there is lack study which actually traces possible similarities between the two. This paper illustrates the distinct description of the two organizations from the perspective of Clifford Geertz in his prominent work, the Religion of Java, where it covered some characteristics of the followers of both Muhammadiyah and Nahdlatul Ulama. This study then continues with possible similar identification of Muhammadiyah and Nahdlatul Ulama. This is qualitative study conducted through library research. This study concludes that despite the fact the differences, there are some similarities, which put the two organization together to contribute even more to the development of Islam in Indonesia. It then expects that the followers of both could work together to build peaceful Indonesian through better understanding of religious institutions such as the Muhammadiyah and Nahdlatul Ulama.

Keywords: Muhammadiyah, Nahdlatul Ulama, Clifford Geertz.

\section{Introduction}

Muhammadiyah and Nahdlatul Ulama (NU) are two biggest organizations in Indonesia, not only in terms of their followers, but also their activities, which include public service in health, education, and religious institutions (Jainuri, 1992; Sukma, 
Joewono, \& Centre for Strategic and International Studies., 2007). They equally play a significant role in terms of Islamic development in Indonesia, since almost all of Indonesian Muslim belongs to the two big organizations officially or not. In addition to that, they both are expected equally to extent their role not limited only in the religious matters, but broader to the maintain the Republic against people who threaten the form of the state which accommodate the major number of Muslims, but also others with distinct religious backgrounds and faith affiliations.

Although there are no questions about their significant role to improve the quality of Indonesian Muslim through their programs and contribute to the existence of the Islam Nusantara (Al-Zastrouw, 2017). Many people form villages have been empowered and having high positions in the society. They later return the favor to contribute to the society. Their programs are also similar in many aspects. They both shared the educational institution both in religious aspects and also the one to accommodate secular system. They are also supportive to the government and work hand in hand to provide prosperous umat under the Republic country. Taking those facts into account; however, a majority of scholars categorize them in two different polar, namely modernist and traditionalist. In this paper, I will use the word 'modernist' to refer to the Muhammadiyah and 'traditionalist' and also 'conservative' for the Nahdlatul Ulama. The last term is particularly to accommodate the idea form Clifford Geertz, in which this paper will take some focus and considerations (Geertz, 1984).

The Author is aware of the distinct categorization of the Muhammadiyah and Nahdlatul Ulama as the scholars put it so (Asyari, 2010; Jainuri, 1992). However, this paper will trace possible similarities between the two. This paper illustrates the distinct description of the two organizations from the perspective of Clifford Geertz in his prominent work, the Religion of Java, where it covered some characteristics of the followers of both Muhammadiyah and Nahdlatul Ulama. This study then continues with possible similar identification of Muhammadiyah and Nahdlatul Ulama. In short, this paper would like to ask how Geertz characterized the two distinct organizations and is there any possible way to put the Muhammadiyah and Nahdlatul Ulama in a same character to make them able to contribute more to the Republic of Indonesia?

This study signifies the importance of the two organization to help build the society and maintain the peaceful society in Indonesia (Asyari, 2010; Blackburn, Smith, \& Syamsiyatun, 2008; Sukma et al., 2007). As the author understands that both organizations 
are expected to make their followers of both could work together to build peaceful Indonesian through better understanding of religious institutions. The Islamic organizations are assets that belong to the category of civil society that can play a role in maintaining the integrity of a nation and state. Indonesia is fortunate to have two largest organizations that have a moderate attitude. It should also be understood that moderate attitudes of Muhammadiyah and Nahdlatul Ulama (Darajat, 2017) have been established and existed since the period prior to Indonesian independence. This consistency is something to be grateful for this becomes a solid asset to maintain the integrity of the nation and state. Therefore, maintaining the integrity of the nation by maintaining the good of these two great organizations is certainly something very good.

\section{Research Method}

This research analyzes possible similar identification of Muhammadiyah and Nahdlatul Ulama with consideration from the perspective of Clifford Geertz (Geertz, 1984). It seeks what characteristics did Geertz illustrated about Muhammadiyah and Nahdlatul Ulama, and then the author identified some similarities, which put the two organization together. Hence one of the appropriate ways to answer the question is by analyzing the existence data through library research (Bryman, 2004, 2008; Creswell, 2013).

The library research has been one of prominent research approach among the students of social sciences or humanities where commonly religious studies of Islamic studies attach to. The library research can follow some steps to make sure the method works for the researchers. The first step is identifying the research topic. In this case, the topic is Geertz's understanding on the Muhammadiyah and the Nahdlatul Ulama. The second step is find the context. The context here is for sure the characteristics of the Muhammadiyah and the Nahdlatul Ulama, particularly, the researchers aim for possible similarities of common ground between the Muhammadiyah and the Nahdlatul Ulama followers. The third step is the main step which is finding the books. There is one main source for this library research which is the Religion of Java. This book is might be the most compressive account of ethnography about people in Java regarding their religiosity. One of the main thesis originated from this book is the dichotomy of the santri, abangan, and priyayi. This has been a debatable topic among scholars who support and again the trichotomy of Muslims in the Javanese. There are numerous publications who has been written both against or supportive to the idea of Clifford Geertz. 
The fourth step is finding the articles. This step is quite similar to the previous one. It is just the kind of the source is different. More and more, the researchers is required to cite from the journal articles as they have been seen to have some advantages, one of them is to provide the cutting edge of the research findings which is something that needs to be quoted. The academic world also has witnessed an increase in the journal article publication both in the local and international levels. The fifth step is evaluating the sources. Along the way of research might develop and became more mature. This might require some evolution of the source selections. The sixth step is citing the sources. This is when a researcher finally quotes the ideas of opinion or findings from other author in their works that fit into research agenda to answer the research questions.

In this particular study, the main source is the Religion of Java (Geertz, 1984). This is a source to understand what Geertz said about the followers of Muhammadiyah and Nahdlatul Ulama. Moreover, this research also aims to uncover the similarities between the two organization. Therefore, more identification on wider literature was completed. This study, however, has some limitations. It focuses on the characteristics of both Muhammadiyah and Nahdlatul Ulama from the perspective of Geertz and therefore, might put aside other scholars' idea. This is not to neglect them, rather to find a focus of study.

As mentioned above, some people differentiate Muhammadiyah and Nahdlatul Ulama, this paper will examine both are integrated each other for certain extents rather they conflict. In this paper, I also make some limitations; Geertz explains modern as Muhammadiyah and Masyumi while Nahdlatul Ulama considered as conservative, but this paper will describe Muhammadiyah as the representative of the modern and Nahdlatul Ulama as the conservative group (Geertz, 1984).

\section{Research Finding}

\section{About Clifford Geertz}

This section will talk about who Clifford Geertz is and why he is an important figure to be discussed in this paper. This has been taken mostly from obituary for Geertz (Kuper, 2006).

Briefly Clifford Geertz is the most influential anthropologist of his generation. Geertz is the author of numerous works that many researchers refer to, even today. His work is on religion, politics, economy and people of Java, Bali and Morocco. In two countries (Indonesia and Morocco) this is the source of information which is then written 
by Geertz. His prominent work begins with The Religion of Java, published in 1960. Meanwhile, his last monumental work is Negara: The Theater State in Nineteenth Century Bali (1980). In addition, there are also well-known works of Islam Observed: Religious Development in Morocco and Indonesia (Kuper, 2006).

Geertz was born in San Francisco and died at the age of 80 years in Princeton, NJ. Not much is known about his childhood and it appears that Clifford Geertz himself did not tell much about his childhood. He worked for the Institute for Advanced Study in Princeton, NJ until the end of his life and he was Professor Emeritus. He is said to be the most influential anthropologist in America for three decades by his colleagues. Clifford Geertz went on to study at graduate school at Harvard and with his wife Hildred they both went to the school of social relations, a new inter-disciplinary social science programme designed by Talcott Parsons. In 1952 Clifford and Hildred went to Java with a team from Harvard University. They are asked to study religion and family life, two things that are considered as the main obstacle to progress in society. Clifford spent two years in Java and one year in Bali. In his report Geertz said that 'religious differences were yielding to a new, nationalist secular ideology'. In 1963 he claimed that he saw a "beginning of fundamental transformation in social and institutional values against patterns we commonly associate with advanced economies." Nevertheless, this optimism was ultimately intangible because shortly afterwards Indonesia suffered because of violent in the range 1965-1966. So, just before the event erupted, Geertz eventually shifted his field to Morocco. The results of his research in Morocco and also in comparison with in Indonesia he published with title Islam Observed (1968). This is a comparative study of Islam in Morocco and Indonesia (Kuper, 2006). With this regards, Geertz was an important scholars who has world reputation and had expertise on Indonesian Islam and society, hopefully from his we as Indonesian could learn a great deal to understand our society and make that understanding for a better future of the nation-state of Indonesia.

\section{Muhammadiyah and Nahdlatul Ulama through the Santri Classification of Geertz}

Clifford Geertz, a well-known anthropologist, while seeing the santri variant, as part of his trichotomy (santri, abangan, and priyayi) of Muslims in Javanese island of Indonesia, said that Mojokuto umat was subdivided, in one hand MasyumiMuhammadiyah, and on the other hand, Nahdlatul Ulama. Geertz then added that almost without exception, every santri considered himself as a follower of one or the other group 
(Geertz, 1984, p. 175) and there was opposition between Masyumi-Muhammadiyah and Nahdlatul Ulama. The first was labeled as modern and the second as conservative. There was some evidence for this differentiation. One of them is that while Nahdlatul Ulama considers custom for details ritual, the Masyumi-Muhammadiyah takes general ought from the Koran and justify them pragmatically (Geertz, 1984, p. 158).

Although the technical terms of 'modernist' and 'conservative' might be familiar in daily usage, in fact, the interpretation of modernist and conservative when related to Islam has some complex meanings: the categorization has multi-dimensional, includes religious thought, geographic and founder of the organization. Therefore, this categorization is nothing easy and to put them even in the same table, might be even harder (Prasetyo \& Munhanif, 2002, p. 28). Thus, in my opinion, this study becomes important, since the theoretical understanding may influence the reality. So, if one can show the conflict factors between them, it may understand as it is. In contrast, if one can emphasize the integration's points, as a result one may understand like it is as well.

\section{Cultural and Structural Conflict}

The conflict between Muhammadiyah and Nahdlatul Ulama began from cultural aspects. Muhammadiyah came with tajdid (reformation) spirit, which has a purification characteristic that wants to clean Islamic thought from local culture, which is not keeping with the true spirit of Islam (Nashir, 2015). That is culture which many conservative's life with. The reason why the culture must be eliminated is because it is blocking the Islamic movement. In contrast, Nahdlatul Ulama sees the culture is enriching the application of Islamic thought. So, the cultural conflicts cannot be avoided. In this sense, it might be true that the emergence of Nahdlatul Ulama in 1926 was the antithesis of Muhammadiyah which was founded earlier in 1912.

The clash then continues with structural conflict by the establishment the political organization. Muhammadiyah which begins from cultural movement, then become structural intuition when joined Masyumi. Almost all-to not call all-members of Muhammadiyah prefer to join Masyumi rather than Nahdlatul Ulama. So, the structural conflict has just begun. The conflict then becomes worst by the not proportional government policies. In the Soekarno era with NASKOM, the government accommodates Nahdlatul Ulama and ignores Muhammadiyah, On the other hand, Soeharto in his era with 
Golkar, pays big attention to Muhammadiyah than Nahdlatul Ulama (Abd Rohim Ghazali, 2000, pp. 9-11).

\section{What Geertz Says}

Geertz argues that people still inevitably distinguish between Muhammadiyah and Nahdlatul Ulama, the first is modern while the other is conservative. There are contrast acknowledgements for the conflict between them. Here are the summaries of the comments of three representatives of the Muhammadiyah, Nahdlatul Ulama and MasyumiMuhammadiyah (Geertz, 1984, pp. 148-149).

First of all, the secretary of Muhammadiyah states that the main difference between Muhammadiyah and Nahdlatul Ulama is that the first one is conservative while the second is modern. Muhammadiyah wants to combine west and east while Nahdlatul Ulama wants only the second. Conservatism is the idea to preserve traditional values. This term initially comes from the Latin, conservāre, which means to preserve. For sure the conservative people also have some different opinion about this. Some might want to keep the old values in this modern era. Or there might be some people who want to go back to the traditional age. For the Nahdlatul Ulama members, they show the attachment to conservatism through the traditional attire when going to perform 'ibādah or worship like salat or prayers. The members of the Nahdlatul Ulama they wear sarong and black peci to identify themselves ready to salat.

On the other hand, modernism is a term that refers to a $19^{\text {th }}$ century and early $20^{\text {th }}$ century phenomenon of transformation in the Western societies that shaped by the industrial rapid development. Modernism is not only merely discussing about the economic issue, but also affects the human point of view, because modernism can also be seen as a movement of change that is philosophical in nature. This makes and changes the viewpoint and human point of view in a massive way. Modernism may be initiated from themes that include arts, architecture, literature, religious beliefs, philosophy, social organization, daily life activities, and even science. Modernism alters the human point of view which then feels that the things that can be done so far are obsolete and no longer in accordance with the developments and demands of the times. Times that demands everything to be fast and connected.

In this regard, we can see why the Muhammadiyah leaders proposed to wear modern uniform to go to school, similar to the Western society. Also, when some of them tend to 
use the western suit instead of sarong and black peci. While the traditionalist NU like to use the traditional sarong and unique black peci as their way of showing their identity.

Secondly, it is interesting that Nahdlatul Ulama agrees to be labeled as kolot. The secretary of Nahdlatul Ulama states that Nahdlatul Ulama is a conservative organization; the people like to be called as conservatives. In addition, he defines kolot by saying that the people like to wear sarong and wood sandals. However, that is not saying that conservative people are who living in the village only, because the point is the heart, living in the village or the town is really does not matter, as long as their heart is kolot. Thirdly, a rank and file member of Masyumi and Muhammadiyah said that compared to Masyumi, Nahdlatul Ulama more interested in religious than politics, Nahdlatul Ulama has many kiyais, they are experts in religious but do not understand how to rule the state.

In the Religion of Java, Geertz clearly mentioned some different characteristic of modern group and the conservative. The contrast can be seen as follows (Geertz, 1984, pp. 149-150):

1. The modern tends to emphasize the relationship between man and God by stating that a success is highly related to hard work, while the conservative tends to relay on God's power.

2. The conservative group tends to hold a totalistic concept on the role of the religion in life. While the modern group tends to hold a narrow notion of religion.

3. The modern pays more attention about the purify of Islam, unlike the conservative who pays less attention. The conservative still allows non-Islamic rites at least in minor aspect of religious life.

4. The conservative group tends to put stressing in the immediately consummate aspect of religion to emphasize religious experience, while the modern tends to emphasize the instrumental aspects of religion to be concerned to the devout behavior.

5. The kolot group tends to justify the practice by custom and by detailed scholastic learning in traditional religious commentaries. The modern group tends to justify it upon the basis of its pragmatics value in contemporary life and by general references to the Koran and the Hadith interpreted loosely.

The conflict also because conservative rely more on culture and sometimes the kiayi establish a law by their interpretation. The modern does not accept the custom which is not 
keeping with the true spirit of Islam, when they find the Islamic one, they then add with rational reason, for example, the early-morning prayer is said to get one out of bed early in the morning so that the one can get right to work and not too lazy around the bed, circumcision as preventing genital infection (Geertz, 1984, pp. 158-159).

To get to authority in religion, the modern group refers directly to the Koran and Hadith, while traditionalists refers to the leader of a sect in Islam. The conservative feels it's not easy to refer directly to the two sources, since they have to master much knowledge, like linguistic, history, and logic. In addition, the time when we live and the prophet lives, so to connect that condition traditionalist feel they need to take mazhab (schools of Islamic law in Islam) (Prasetyo \& Munhanif, 2002, pp. 38-39).

Geertz continues his description about the disagreement among modern and conservative in many topics, to see that Muhammadiyah and Nahdlatul Ulama are different. For instance, in context of the fate versus self-determination, the conservative emphasizes the fate in the life. They believe that the power of God determines every single detail of human behaviors. On the other hand, the modernist group uses the Koranic commands to work in order to meet the needs. While believing in the destiny, they also believe that an effort makes difference. With this believe they can criticize the situation better, for example: when somebody says that we can just be patient about be poor people, he says that the poor are not coming from God, it comes because they are lazy (Geertz, 1984, pp. 150-152).

Around the study of totalistic versus narrow religion. The conservative group emphasize religious affairs, compared to modern people who emphasize more on secular affairs. Conservative think that Islam has adequate and explicit direction in all fields of human endeavor from the domestic to the politics, so they ask: how this secular life can be justified in terms of religion?

A simple example is: the conservative group may say that wearing western dresses as infidel practice, while the modern group has no problem with that (Geertz, 1984, pp. 152153). The other point is about syncretic versus puritan Islam. The conservative may be defined as syncretism Muslim, they are permissive to the abangan and priyayi rituals, for example, they are still doing slametan, although they make many changes for that, they try to emphasize the Islamic point from non-Islamic points. Different from them, the modern group tries to be puritan Muslim, they, for example, criticize the people who doing mystic. 
They do think that is wrong and the people are egoistic, since they left their family with nothing to get their wishes in terms of the mystics (Geertz, 1984, pp. 153-155).

So, from the description above, clearly there are many conflicts among Muhammadiyah and Nahdlatul Ulama, later we will see what we conclude at the end. It might not be surprising if I could have different opinion about this thesis.

\section{Contemporary Examples}

After seeing some points where Muhammadiyah and Nahdlatul Ulama are treated as two different groups, this part will try to explore the integration factors in contemporary examples. Abd. Rohim Ghazali states that Muhammadiyah and Nahdlatul Ulama are like two same-sex children play in one room. They are powerful organizations, they claim to have thousand million followers, and do Islamic teaching, in one state: Indonesia. So, we need to be careful in watching them in order to protect them not to fight. Ghazali then added, although many scholars categorize them, but in fact, they mix each other (Abd. Rohim Ghazali, 1999, pp. 13-14).

The idea of reconciliations among Muhammadiyah and Nahdlatul Ulama also came from the authors of Islam and Civic Society. The view of Indonesian Muslim who distinguishes the relationship between traditionalist and modernist in three different kinds of relationship. First of all, in pre-independence and in the early time of independence, both are in formative era, where, ideology, asset value institutionalized, and characteristic building was going on, the second, in old order, both are competition in almost every sector, and thirdly, the difference between the two is eliminated, and much integration and similarity, so the distinguish is not really based and only in one or two aspects only (Prasetyo \& Munhanif, 2002, pp. 51-52).

The opportunity to reconsolidate began from new order, when the governments simplified the party in three, this force the Nahdlatul Ulama and Muhammadiyah members to integrate and make interaction. Secondly, the social state became better, and it eliminated the border between them. Thirdly, education. From now on, the dichotomy is eliminated, the small politic space force Muslim to work in the cultural system like dakwah, education economics, culture etc., this also gave them the opportunity to interact with each other. Time by time the dichotomy is eliminating (Abd Rohim Ghazali, 2000, pp. 59-60). 
The sign that the relationship among Muhammadiyah and Nahdlatul Ulama will be better also sated bay Ahmad Bagja. He States that Muhammadiyah and Nahdlatul Ulama have a same view in terms of social affairs. This is because the progress on communication, for example: there are direct silaturahmi, visiting, together ritual, etc. among Muhammadiyah and Nahdlatul Ulama members (Abd Rohim Ghazali, 2000). Bagja adds that: Muhammadiyah and Nahdlatul Ulama "have" politic parties, which have same targets, both are in one department at the state, namely the department of religious affairs (Abd Rohim Ghazali, 2000).

The other factor for reconciliation is that, there is a theory that the custom which is not keeping with the true spirit of Islam, which force the emerged Muhammadiyah eliminates time-by time for the development in sciences and technology. In addition, the not-proportional political is now past, but the both are helping and supporting each other in terms of reformation and reject corruption. So in the other words, the motive of the conflict is irrational, they can be welded in harmony (Abd Rohim Ghazali, 2000).

Gus Dur mentioned a story: One day, Hasyim As'ari-the founder of Nahdlatul Ulama-told that there is a new organization, namely Muhammadiyah was founded in Yogyakarta. As'ari then asks: who is the founder? It answered that the founder is: K.H.A. Dahlan. Ooo...Kiyai Haji Ahmad Dahlan who studied with me in Kiyai Soleh Darat's pesantren in Semarang, said Hasyim As'ari. Yes, he is, replied to the person. As'ari then states: O, there is nothing (no problem of the organization) (Abd Rohim Ghazali, 2000, p. 25). Ghazali also says that many top leaders of both Muhammadiyah and Nahdlatul Ulama still communicate each other and make good relationship for a long time, for example: Kiyai Masykur and Fakhruddin, Gus Dur and AR Fakhruddin, Azahr Baasyir and Amin Rais (Abd Rohim Ghazali, 2000).

So, it is clear that even among the leader, there are integrated each other's. The theory and facts above then can be some good reasons to see the integration between Muhammadiyah and Nahdlatul Ulama as representatives of Modern and Conservatives groups. This also give us evidence that a more intelligent person a wiser person as along with their the development of their knowledge they know more and accommodate other point of view. This idea needs to be brought to the society and expect them to learn to truly understand other people. We will now see the recent examples in the reality.

In the past, referring to the leader of the religious sects in the conservative group is so important, this time, the trend is changing. The conservative is now moving from 
mazhab qauli into mazhab manhaji. The first one is what is known as referring to the sect's leaders opinion, unlike the contrast, that using a mazhab methodologically, this is will enable new possibilities to the social transformation, politic economic and culture (Alaena, 2000, pp. 140-141). In terms of religious thought, there also good progress, aswaja still as a great role for conservative group, but there were people who can eliminate the dichotomy like: Nurcholis Madjid and Gus Dur. Their thought compromise the problem between them (Abd Rohim Ghazali, 2000, p. 62).

Tajdid is a popular term of Muhammadiyah, means reformation. However, interestingly, the Nahdlatul Ulama also has a new paradigm about tajdid, namely: keeping the old goods and taking the better from the new (Thoha \& Mustofa, 1997, pp. 176-177).

A clearest example is probably; the ritual meetings between Muhammadiyah and Nahdlatul Ulama members on 26 September 1999 were presented: KH Abdurrahman Wahid, Prof, H.M. Amin Rais, Dr. KH. Nur Muhammad Iskandar, Prof. Dr. Said aqil siradj, DR. M. Din Syamsuddin, Drs. Imam Addaruquthni and Saifullah Yusuf. They are Nahdlatul Ulama and Muhammadiyah leaders and scholars. The ceremony was recorded in a cassette, but it does not only record a sound, but more, it recorded a history, when Muhammadiyah and Nahdlatul Ulama are can be united (Abd. Rohim Ghazali, 1999, pp. 5-7).

The other fact is also when Amin Rais supported Gus Dur as a forth president of Indonesia. They support each other's in order to make a better state. So, there are many clear examples that show up how Muhammadiyah aa representative of modern group and Nahdlatul Ulama as what some people called as conservative can be joint together and integrated.

From the Buku Pendidikan Kemuhammadiyahan Kelas X, it can be summarized that the Muhammadiyah's efforts include these 14 programs, namely:

1) It instills confidence, deepens and broadens understanding, enhances experiences, and disseminates Islamic teachings in various aspects of life.

2) Deepen and develop the study of Islamic teachings in various aspects of life to obtain purity and truth.

3) Increasing the spirit of worship, jihad, zakat, infak, waqf, shadaqah, grants, and other good deeds.

4) Improving the dignity, dignity, and quality of human resources to be highly capable and berakhlaq noble. 
5) Advancing and renewing education and culture, developing science, technology and the arts, as well as improving research.

6) Advancing economy and entrepreneurship towards quality improvement of life.

7) Improve the quality of community health and welfare.

8) Maintain, develop and utilize natural resources and environment for prosperity.

9) Developing communication, ukhuwah and cooperation in various fields and society at home and abroad.

10) Maintaining the integrity of the nation and play an active role in the life of nation and state.

11) Foster and improve the quality and quantity of members as actors of the movement.

12) Developing facilities, infrastructure, and financial resources for the success of the movement.

13) Seek law enforcement, justice and truth, and increase the defense of society.

14) Other efforts in accordance with the aims and objectives of Muhammadiyah.

If one analyses the above programs, it is not surprising if many of them are similar to the efforts of the Nahdlatul Ulama. It might be with a different term or name, but the essence is similar.

\section{Is Geertz's Explanation Invalid?}

After describing many factors of integration between modern and conservative, one might think that Geertz, who distinguishes Muhammadiyah and Nahdlatul Ulama is incorrect, however, in my opinion, Geertz is not wrong for several reasons.

First of all, in his book, Geertz also cites the opinion of the Atmilan, who argues that the opinion states that Nahdlatul Ulama is kolot, Muhammadiyah is modern, etc., was not true, they all come from Islam, and it is all about a matter of steering an automobile, so they need many parties, so this is all about politics (Geertz, 1984, pp. 175-176). By this, I think that Geertz aware that there is no solid line between modern and conservative. Geertz also states that in the reality the picture which differentiates Nahdlatul Ulama and Muhammadiyah is not clear but fuzzy (Geertz, 1984, p. 161).

What Geertz made to his book was approaches how to make some point that can bring one group to one side and another group to another side. This is necessary to explain a good penetration of political organizations in Mojokuto that influence non-political aspects of life among both leader and follower (Geertz, 1984, p. 176). 


\section{Conclusion}

Some people may see that there is a big gap between Muhammadiyah and Nahdlatul Ulama. They can come with many examples from the past. This might be ranging from the perspective of how they perceive west and east. Also, the perspective of modern and conservative. However, in my opinion, the gap is getting smaller and smaller time by time. Many old points that differentiate between the modern and conservative are irrelevant. The tension between the members of both Muhammadiyah and Nahdlatul Ulama is also comparatively low compared to the old times. And on the other hand, there are many examples that show us how the two big organizations are integrated each other. So rather than conflict, there are more factors that can integrate them. The possibility can come by the development of the sciences, politic and interaction between the members.

The current government also perceive both Muhammadiyah and Nahdlatul Ulama as two important assets of the nation state to keep this country in a stable condition and situation. The government expects the two biggest organizations to work hand in hand for the better future of the nation. This integration will bring more opportunities that will enable both organizations to contribute more on the development of Indonesian in this Republic.

\section{Bibliography}

Al-Zastrouw, N. (2017, January 30). Mengenal Sepintas Islam Nusantara. Hayula: Indonesian Journal of Multidisciplinary Islamic Studies, 1(1), 1-18. https://doi.org/https://doi.org/10.21009/hayula.001.1.01

Alaena, B. (2000). N.U., Kritisisme, dan Pergeseran Makna Aswaja. Yogyakarta: Tiara Wacana Yogya.

Asyari, S. (2010). Traditionalist v.s modernist Islam in Indonesian politics: Muhammadiyah \& Nahdlatul Ulama (NU) in the Contemporary Indonesian Democratic and Political Landscape. VDM Verlag Dr. Müller, Saarbrücken.

Blackburn, S., Smith, B. J., \& Syamsiyatun, S. (2008). Indonesian Islam in a new era: How women negotiate their Muslim identities. Clayton, Vic.: Monash University Press.

Bryman, A. (2004). Social Research Methods (2nd ed.). Oxford: Oxford University Press. Bryman, A. (2008). Social Research Methods. Oxford: Oxford University Press. 
Creswell, J. W. (2013). Qualitative Inquiry \& Research Design: Choosing among Five Approaches. Thousand Oaks, Calif: SAGE.

Darajat, Z. (2017, January 30). Muhammadiyah dan NU: Penjaga Moderatisme Islam di Indonesia. Hayula: Indonesian Journal of Multidisciplinary Islamic Studies, 1(1), 81-96. https://doi.org/https://doi.org/10.21009/hayula.001.1.05

Geertz, C. (1984). The Religion of Java. Chicago: University of Chicago Press.

Ghazali, A. R. (1999). Gus Dur dalam sorotan cendekiawan Muhammadiyah. Bandung: Mizan.

Ghazali, A. R. (2000). Dua yang Satu: Muhammadiyah dalam Sorotan Cendekiawan NU. Bandung: Mizan.

Jainuri, A. (1992). The Muhammadiyah Movement in Twentieth-Century Indonesia: A Socio-Religious Study. (M.A.), McGill University (Canada), Ann Arbor.

Kuper, A. (2006). Clifford Geertz. The Guardian. Retrieved from https://www.theguardian.com/news/2006/nov/15/guardianobituaries.obituaries

Nashir, H. (2015). Muhammadiyah a Reform Movement.

Prasetyo, H., \& Munhanif, A. (2002). Islam \& Civil Society: Pandangan Muslim Indonesia.

Sukma, R., Joewono, C., \& Centre for Strategic and International Studies. (2007). Islamic thought and movements in contemporary Indonesia. Jakarta: Centre for Strategic and International Studies.

Thoha, Z. A., \& Mustofa, M. A. (1997). Membangun Budaya Kerakyatan: Kepemimpinan Gus Dur dan Gerakan Sosial NU. Yogyakarta: Titian Ilahi Press. 
